\title{
Valorization of SiMn Sludge for Production of Low-Phosphorus Ferroalloys
}

\author{
M. Wallin ${ }^{1} \cdot$ A. Voll Bugten ${ }^{1} \cdot$ G. Tranell ${ }^{1} \cdot$ K. E. Ekstroem ${ }^{1}$ (D)
}

Received: 12 October 2020 / Accepted: 28 May 2021 / Published online: 22 June 2021

(c) The Author(s) 2021

\begin{abstract}
The sludge generated by wet scrubbing the off-gas from a silicomanganese plant in Norway represents a significant loss in silicon and manganese values. This work seeks to extract these values in the production of ferroalloys and slags that can be utilized by alternative industries. Carbothermic smelting the sludge together with iron or iron scraps at $1600{ }^{\circ} \mathrm{C}$ produced FeSiMn alloys consisting of 57-64 wt.\% Mn, 16-22 wt.\% Si and 18-25 wt.\% Fe. The low level of phosphorus in the sludge allowed for beneficial phosphorus concentrations as low as $500 \mathrm{ppmw}$ in the metal alloys. The addition of lime to the material mix resulted in increased evaporation of alkalis, capture of sulfur in the slags as calcium sulfides and slag compositions similar to conventional steel-making slags that can be recycled accordingly.
\end{abstract}

\section{Graphical Abstract}

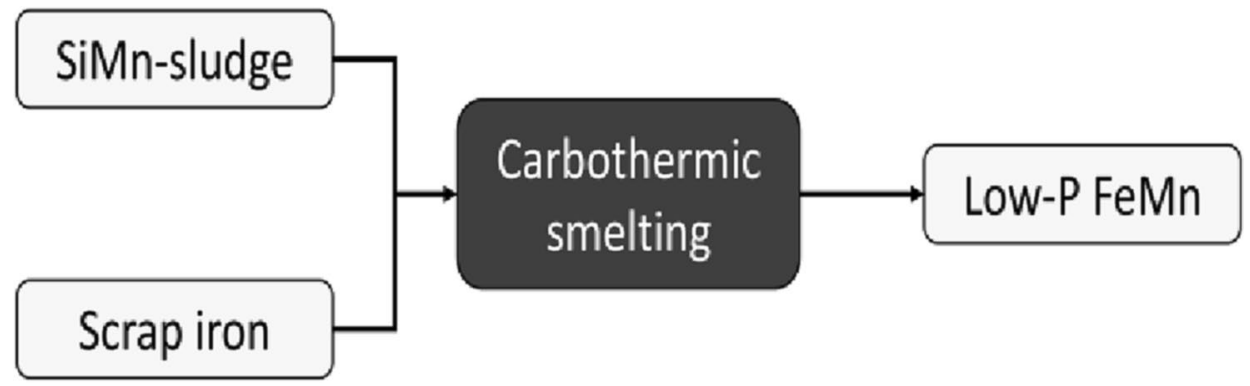

Keywords Silicomanganese $\cdot$ Recycling $\cdot$ Metal recovery $\cdot$ Ferroalloy

\section{Introduction}

Metallurgical dust fractions generated during metal production are commonly captured through wet scrubbing of the off-gas, and these sludges may contain significant metal values. However, due to high conversion costs and properties not compatible with the daily operations of the furnace, they are rarely recycled by the plants. Instead, the sludges are collected in landfills for inexpedient storage. The significant

The contributing editor for this article was Sharif Jahanshahi.

K. E. Ekstroem

kai.e.ekstrom@ntnu.no

1 Norwegian University of Science and Technology, Trondheim, Norway material losses, environmental impact of such landfills, and establishment of circular principles have at the same time parked interest among industrial actors, lawmakers, and the general public to develop new strategies and technologies for recycling of sludges. Stricter regulations like the Extractive Waste Directive (2006/21/EC) and the European Waste Legislation put new constraints on landfilling and increase the pressure on the industry to find alternative and more sustainable solution for handling their wastes [1]. The Norwegian Waste-to-Value project was a part of an ambitious plan to develop technologies for better utilization of waste products from industrial partners.

The off-gas collected from production of silicomanganese (SiMn) at the Eramet Kvinesdal plant is scrubbed with water and converted into a thick aqueous sludge for deposition in 
local settling ponds. The plant generates approximately 10000 metric tons of sludge annually and has been subject to various studies over the years $[2,3]$. Direct recycling into the submerged arc furnace (SAF) has proven to be challenging, due to the high tar and water content, and the presence of alkalis and unwanted circulation of volatiles proved to have negative consequences for the daily operations and energy consumption of the furnace. The authors suggested that the most suitable option was to calcine the sludge, for evaporation of volatiles, followed by smelting in an open bath arc furnace. The generated slag would contain most of the Mn, for reintroduction into the SAF, while alkalis would be removed through the offgas. Experiments were to be performed at a later stage, but any public literature remains absent. An alternative use of the sludge, which acts as the basis for this work, is the possibility of using it as a raw material for direct production of ferromanganese instead. Manganese is an essential component in steelmaking, with varying concentrations of $0.25-30 \%$, where its primary role is to increase the hardenability of the steel and prevent formation of iron sulfides [4]. The low melting point of iron sulfides degrades the high-temperature properties of the steel and may lead to hot shortness. Minimization of sulfur has been prioritized by steel producers for years, and most plants are able to remove small concentrations as a part of their daily routine. However, certain steel products have restrictive specifications on other impurities as well, such as phosphorus, and the demand for such specialized steels is increasing. Conventional steels typically contain $0.05 \% \mathrm{P}$, but concentrations as low as $0.005 \%$ and as high as $0.1 \%$ are also not uncommon. Steels containing manganese, silicon, and titanium are particularly susceptible to embrittlement in the presence of $\mathrm{P}$, especially in corrosive and low-temperature environments. This group of very low-phosphorus steels require phosphorus levels below $0.02 \%$. Dephosphorization is not a trivial process and can be both challenging and costly, emphasizing the importance of locating raw materials that are natively low in phosphorus. However, producers may find themselves in a situation where it becomes necessary to adapt to alternative raw materials as high-grade ores are depleted.

The current work seeks to investigate the possibility of using the SiMn sludge together with iron sources for producing ferromanganese (FeMn) alloys and slags that can be utilized by alternative industries. The low phosphorus level of the sludge, which is comparable to typical high-grade manganese ores, may also prove to be especially useful for producing lowphosphorus alloys [2, 4].

\section{Materials and Methods}

\section{Thermochemical Calculations}

Equilibrium calculations were performed using FactSage 7.2 thermochemical software in order to design and evaluate the experimental work [5]. Input species are taken from Table 1 and normalized to $100 \mathrm{~g}$ of SiMn sludge. Descriptions of oxide solution, such as liquid slag (SLAG), monoxide (MeO), and calcium silicate solid solution (ac2SA), were taken from the FToxide database. Thermodynamic properties of pure substances and gas species were taken from the FactPS database, and the FSstel database were adopted to calculate the liquid metal (LIQU) solution. Closed system calculations were performed with temperature and pressure fixed at $1600{ }^{\circ} \mathrm{C}$ and $1.0 \mathrm{~atm}$, respectively.

\section{Pre-treatment and Smelting}

SiMn sludge collected from the scrubbers at Eramet in Norway contained approximately $55 \%$ moisture and was dried at $110{ }^{\circ} \mathrm{C}$ for $16 \mathrm{~h}$ prior to pelletizing (Fig. 1a). Carbon black was used as the source of carbon and lime as fluxing material. Iron was added in the form of either pure iron powder (Sigma-Aldrich 12,310-1 KG-R) or iron scrap. The chemical composition of the various raw materials and the

Table 1 Compositional analysis of the raw materials used in this study, given in wt.\%

\begin{tabular}{|c|c|c|c|c|c|}
\hline Species & Sludge & Carbon & Lime & Fe powder & Fe scrap \\
\hline $\mathrm{C}$ & 7.61 & $\geq 99.00$ & - & - & 3.69 \\
\hline $\mathrm{CO}_{2}$ & - & - & $\leq 3.00$ & - & - \\
\hline $\mathrm{Na}_{2} \mathrm{O}$ & 1.04 & - & - & - & - \\
\hline $\mathrm{MgO}$ & 2.83 & - & - & - & - \\
\hline $\mathrm{Al}_{2} \mathrm{O}_{3}$ & 4.56 & - & - & - & - \\
\hline $\mathrm{Si}$ & - & - & - & - & 2.51 \\
\hline $\mathrm{SiO}_{2}$ & 32.26 & - & - & - & - \\
\hline $\mathrm{K}_{2} \mathrm{O}$ & 5.33 & - & - & - & - \\
\hline $\mathrm{P}_{2} \mathrm{O}_{5}$ & 0.05 & - & - & - & - \\
\hline $\mathrm{SO}_{3}$ & 4.02 & - & - & - & - \\
\hline $\mathrm{CaO}$ & 1.17 & - & $\geq 94.00$ & - & - \\
\hline $\mathrm{Mn}$ & - & - & - & - & 0.06 \\
\hline $\mathrm{MnO}$ & 37.61 & - & - & - & - \\
\hline $\mathrm{Fe}$ & - & - & - & $\geq 99.00$ & 93.76 \\
\hline $\mathrm{Fe}_{2} \mathrm{O}_{3}$ & 2.01 & - & - & - & - \\
\hline $\mathrm{ZnO}$ & 0.91 & - & - & - & - \\
\hline $\mathrm{PbO}$ & 0.12 & - & - & - & - \\
\hline $\mathrm{P}$ & 136 & $<5$ & 40 & $<1$ & 12 \\
\hline S & 17,400 & $<20$ & 70 & $<7$ & $<8$ \\
\hline
\end{tabular}

The levels of $\mathrm{P}$ and $\mathrm{S}$ were measured by ICP-SFMS, given in ppmw 

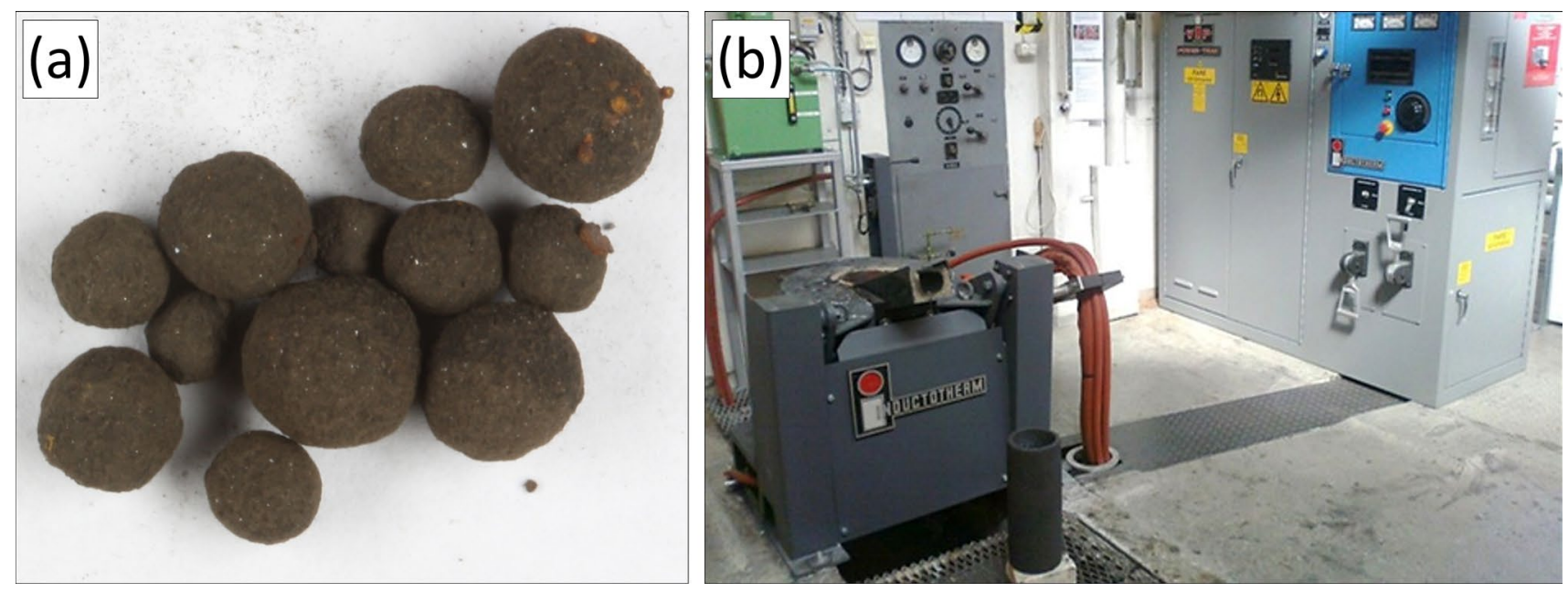

Fig. 1 a Dried and pelletized SiMn sludge farmed from the Eramet Kvinesdal plant in Norway. b Current experiments were smelted in a $75 \mathrm{~kW}$ induction furnace

Table 2 Raw material mixtures used for samples $\mathrm{A}$ to $\mathrm{C}$ in grams

\begin{tabular}{llll}
\hline Raw materials & Sample A & Sample B & Sample C \\
\hline Sludge & 360.00 & 360.00 & 360.00 \\
Fe powder & 20.20 & 20.22 & - \\
Fe scrap & - & - & 21.29 \\
Carbon & 55.58 & 55.57 & 55.57 \\
Lime & 0.00 & 136.83 & 136.83 \\
\hline
\end{tabular}

experimental material mixtures are summarized in Tables 1 and 2, respectively.

Prior to smelting, $360 \mathrm{~g}$ of dried and pelletized $\mathrm{SiMn}$ sludge was mixed with approximately $20 \mathrm{~g}$ of Fe powder or Fe scrap, $55 \mathrm{~g}$ of carbon black and a varying amount of lime in graphite crucibles. The crucibles were placed in an open $75 \mathrm{~kW}$ induction furnace (Fig. 1b), heated to a temperature of $1600{ }^{\circ} \mathrm{C}$ and held for $2 \mathrm{~h}$ in a reductive $\mathrm{CO} /$ $\mathrm{CO}_{2}$ atmosphere established by the carbon source and the graphite crucible. In the case of using Fe scrap, the scrap was pre-smelted at $1200{ }^{\circ} \mathrm{C}$ before adding the rest of the raw materials. The crucible was covered in a layer of insulation to reduce heat loss, and a type-C thermocouple was used to measure the temperature in the crucible.

\section{Characterization}

Phase analysis of the SiMn sludge raw material was carried out by a Bruker D8 A25 X-ray diffractometer (XRD), with $\mathrm{Cu}-\mathrm{K} \alpha$ radiation. Additional elemental analysis of the sludge and final slags was done by a Philips PW 2404 X-ray fluorescence spectrometers (XRF). The slags were separated from the metal fractions and pulverized in a ceramic mortar before analysis. Compositional analysis of the produced metal fractions was carried out by a JEOL JXA-8500F electron probe micro-analyzer (EPMA), fitted with five wavelength dispersive X-ray spectrometers (WDS) and an energy dispersive X-ray spectrometer (EDS). The levels of phosphorus and sulfur in all raw materials were also measured by inductively coupled plasma sector field mass spectrometry (ICP-SFMS).

\section{Results}

\section{Characteristics of Raw Materials}

The primary components of the SiMn sludge were by XRD analysis found to comprise of tephroite, leucite, and quartz, seen in Fig. 2. The elemental analysis in Table 1 complements the XRD analysis in that the sludge consists of manganese oxide $(\mathrm{MnO})$, silicon dioxide $\left(\mathrm{SiO}_{2}\right)$, and carbon (C) as major components. Minor components include alumina $\left(\mathrm{Al}_{2} \mathrm{O}_{3}\right)$, magnesia $(\mathrm{MgO})$, lime $(\mathrm{CaO})$, ferric oxide $\left(\mathrm{Fe}_{2} \mathrm{O}_{3}\right)$, alkalis, i.e., sodium oxide $\left(\mathrm{Na}_{2} \mathrm{O}\right)$ and potassium oxide $\left(\mathrm{K}_{2} \mathrm{O}\right)$, and heavy metals, i.e., zinc oxide $(\mathrm{ZnO})$ and lead monoxide $(\mathrm{PbO})$. The compositional analysis of carbon black, lime, and Fe powder is taken from the specifications of the respective raw materials, except for the content of $\mathrm{P}$ and $\mathrm{S}$. Fe scrap was measured to contain small concentrations of $\mathrm{C}$, silicon $(\mathrm{Si})$, and manganese $(\mathrm{Mn})$.

\section{Thermochemical Calculations}

The distribution of phases resulting from equilibrium calculations at the smelting temperature is plotted as a function of added lime in Fig. 3a. Vertical lines representing the respective lime additions of the current experiment are also 


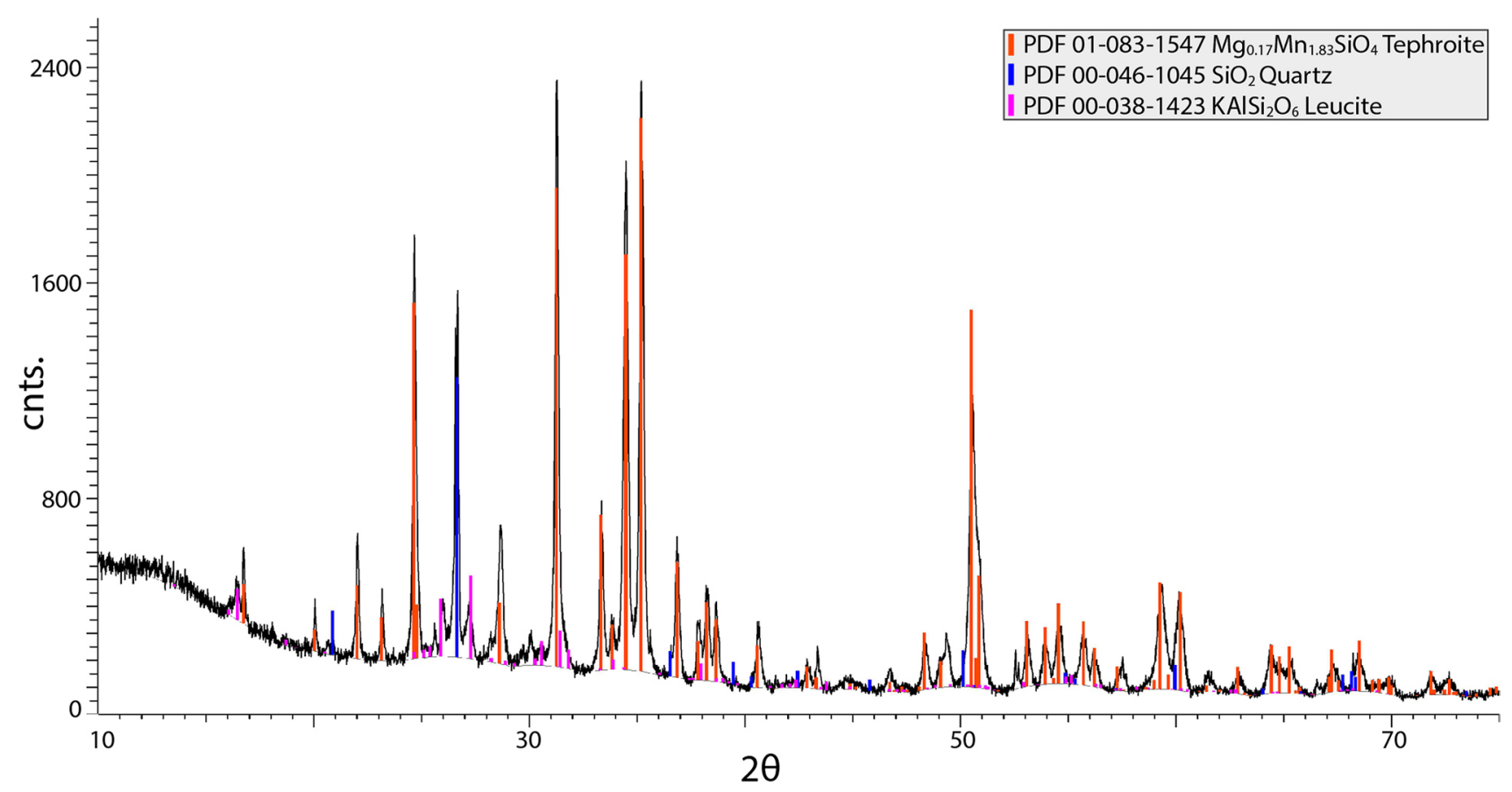

Fig. 2 The XRD diffractogram of the SiMn sludge has been identified to consist of tephroite $\left(\mathrm{Mn}_{2} \mathrm{SiO}_{4}\right)$, leucite $\left(\mathrm{KAl}_{2} \mathrm{O}_{6}\right)$, and quartz $\left(\mathrm{SiO}_{2}\right)$

(a)

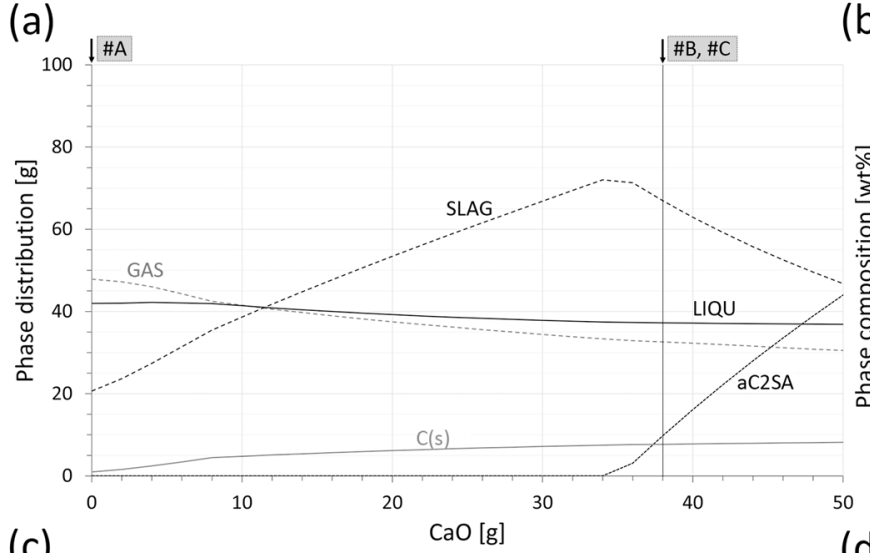

(c)

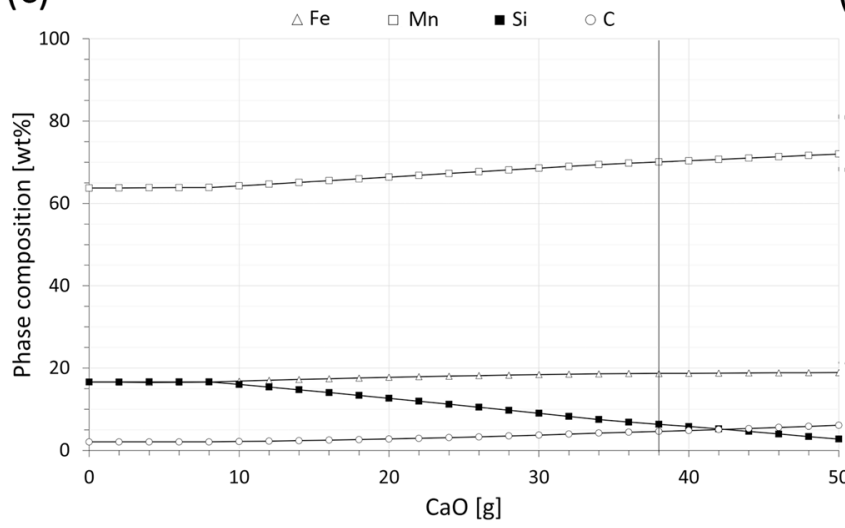

(b)

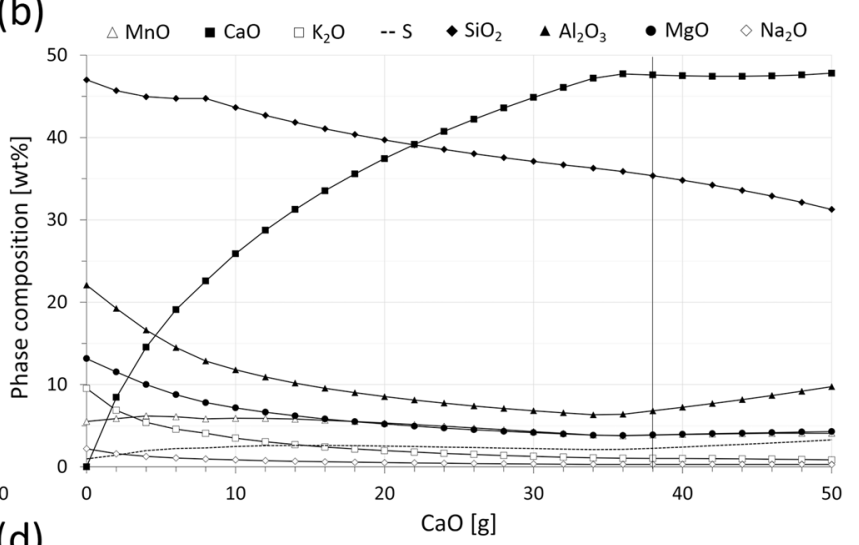

(d)

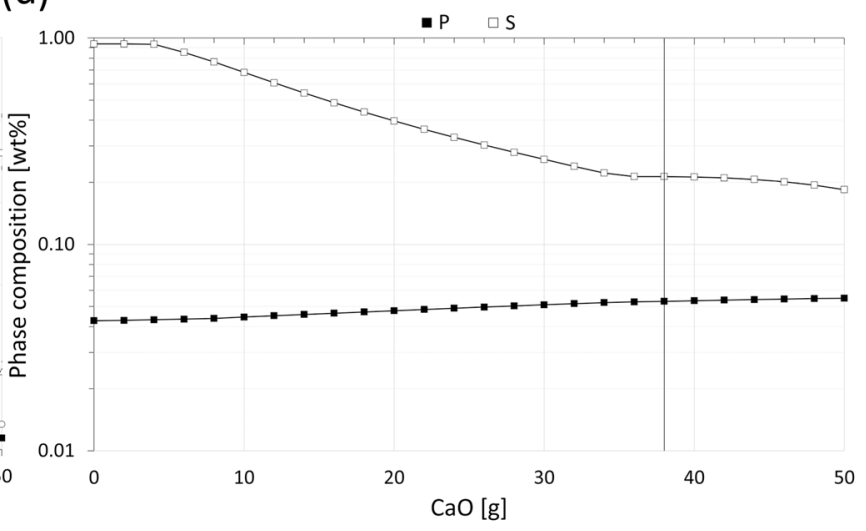

Fig. 3 a The distribution of liquid metal (LIQU), liquid slag (SLAG), gas (GAS), calcium silicate solid solution (aC2SA), and solid carbon, as a function of added $\mathrm{CaO}$. The chemical composition of the $\mathbf{b}$ liquid slag and $\mathbf{c} / \mathbf{d}$ liquid metal, as a function of added $\mathrm{CaO}$ 

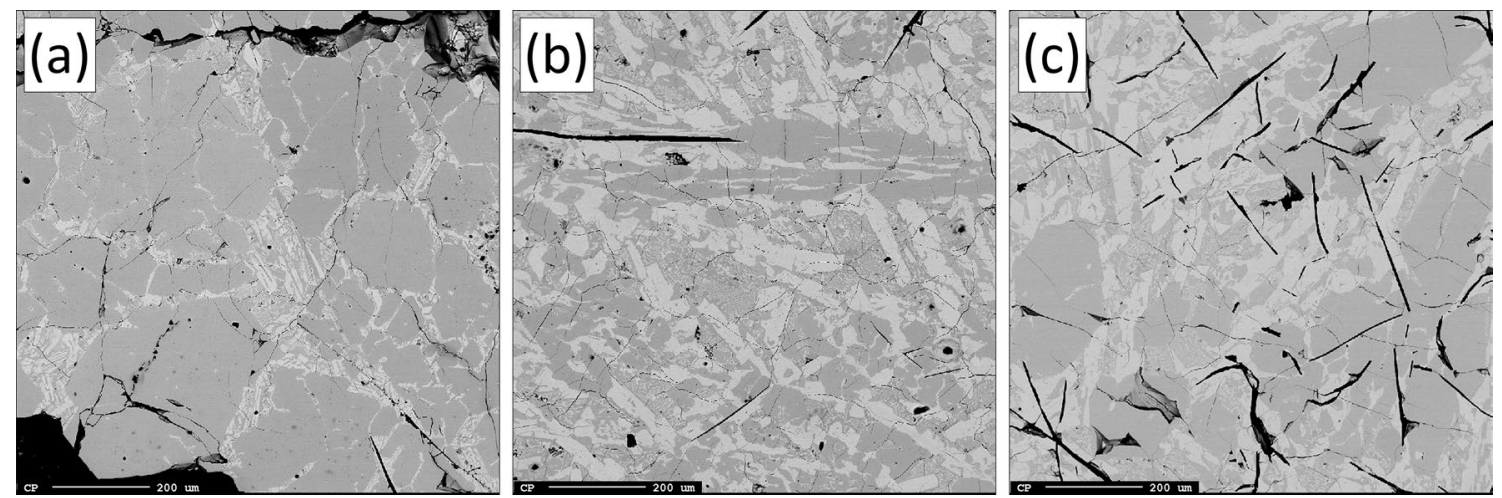

Fig. 4 Backscatter micrographs of metal fractions from samples a A, b B, and $\mathbf{c}$ C. The metals are generally found to consists of two phases, bright and dark, and the respective compositions are summarized in Table 3

Table 3 Summary of metal phase compositions in $\mathrm{wt} \%$, as measured by EPMA

\begin{tabular}{|c|c|c|c|c|c|c|}
\hline \multirow[t]{2}{*}{ \# } & \multicolumn{2}{|l|}{ Sample A } & \multicolumn{2}{|l|}{ Sample B } & \multicolumn{2}{|l|}{ Sample C } \\
\hline & Bright & Dark & Bright & Dark & Bright & Dark \\
\hline $\mathrm{Si}$ & $10.4 \pm 0.1$ & $23.8 \pm 0.1$ & $9.6 \pm 0.2$ & $22.2 \pm 0.2$ & $10.6 \pm 0.5$ & $23.6 \pm 0.1$ \\
\hline $\mathrm{Mn}$ & $68.0 \pm 0.5$ & $56.6 \pm 0.3$ & $71.9 \pm 0.1$ & $58.7 \pm 0.3$ & $63.9 \pm 0.8$ & $53.0 \pm 0.3$ \\
\hline $\mathrm{Fe}$ & $21.6 \pm 0.1$ & $19.6 \pm 0.2$ & $18.5 \pm 0.1$ & $19.1 \pm 0.3$ & $25.5 \pm 0.2$ & $23.4 \pm 0.2$ \\
\hline $\mathrm{P}$ & 498 & & 568 & & 550 & \\
\hline S & 1040 & & 335 & & 309 & \\
\hline
\end{tabular}

The concentrations of phosphorus and sulfur are given in ppmw, as measured by ICP-SFMS marked. The chemical compositions of the liquid slag and liquid metal are also plotted in (b) and (c)/(d), respectively. Addition of $\mathrm{CaO}$ is important for slag formation and the kinetics of slag-metal reactions. The incorporation of added $\mathrm{CaO}$ in the liquid slag is apparent in (b), and the lower activity of $\mathrm{SiO}_{2}$ in the slag drives $\mathrm{Si}$ from the liquid metal into the liquid slag, while $\mathrm{Al}_{2} \mathrm{O}_{3}, \mathrm{MgO}$, and $\mathrm{K}_{2} \mathrm{O}$ show a slight decrease in the liquid slag upon addition of $\mathrm{CaO}$. Solid calcium silicates start to precipitate at high enough $\mathrm{CaO}$ levels. Addition of $\mathrm{CaO}$ has a noticeable effect on reducing the amount of dissolved $\mathrm{S}$ in the liquid metal and is also found to drive off alkalis, i.e., $\mathrm{Na}_{2} \mathrm{O}$ and $\mathrm{K}_{2} \mathrm{O}$, to the gas phase.

\section{Metal and Slag Characteristics}

Smelting produced metal alloys with fairly complex microstructures (Fig. 4). All metals consist of a mixture of two primary phases, which are visible as bright and dark areas in the backscatter micrographs. The different contrasts arise from varying phase compositions, also known as Z-contrast, which is summarized for all samples in Table 3. The phosphorus level of all samples remains relatively constant around 490-568 ppmw. Sample A displays a considerable higher level of sulfur, 1040 ppmw, compared to samples B and C, 309-335 ppmw.
Table 4 Summary of slag phase composition in wt.\%, as measured by XRF

\begin{tabular}{lrrr}
\hline$\#$ & Sample A & Sample B & Sample C \\
\hline $\mathrm{C}$ & 1.74 & 0.34 & 0.55 \\
$\mathrm{Na}_{2} \mathrm{O}$ & 1.57 & $<0.01$ & 0.00 \\
$\mathrm{MgO}$ & 11.05 & 4.38 & 4.74 \\
$\mathrm{Al}_{2} \mathrm{O}_{3}$ & 15.74 & 6.16 & 7.43 \\
$\mathrm{SiO}_{2}$ & 41.00 & 28.28 & 26.77 \\
$\mathrm{P}_{2} \mathrm{O}_{5}$ & $<0.01$ & $<0.01$ & $<0.01$ \\
$\mathrm{SO}_{3}$ & 4.58 & 5.50 & 5.80 \\
$\mathrm{~K}_{2} \mathrm{O}$ & 5.32 & 0.01 & 0.01 \\
$\mathrm{CaO}$ & 5.13 & 48.09 & 48.78 \\
$\mathrm{MnO}$ & 10.33 & 4.89 & 4.50 \\
$\mathrm{Fe}$ & $\mathrm{O}$ & 1.12 & 0.27 \\
$\mathrm{ZnO}$ & 1.31 & $<0.01$ & $<0.01$ \\
$\mathrm{PbO}$ & $<0.01$ & 0.00 & 0.00 \\
\hline
\end{tabular}

A more accurate measure on the levels of phosphorus $(\mathrm{P})$ and sulfur (S) is also summarized for all raw materials in the bottom part of Table 1. With concentrations of $136 \mathrm{ppmw} P$ and $0.017 \mathrm{wt} . \% \mathrm{~S}$, the SiMn sludge is by far, although still low, the largest source of $\mathrm{P}$ and $\mathrm{S}$ in these experiments.

The chemical compositions of the various slags are summarized in Table 4 . Without any added $\mathrm{CaO}$, i.e., in sample 
A, the slag is found to consist primarily of $\mathrm{SiO}_{2}, \mathrm{Al}_{2} \mathrm{O}_{3}$, $\mathrm{MgO}, \mathrm{MnO}$ and lesser concentrations of $\mathrm{CaO}$ and $\mathrm{K}_{2} \mathrm{O}$. On the other hand, in samples with added $\mathrm{CaO}$, i.e., in samples $\mathrm{B}$ and $\mathrm{C}$, the slags are found to consist primarily of $\mathrm{CaO}$ and $\mathrm{SiO}_{2}$, with lesser concentrations of $\mathrm{Al}_{2} \mathrm{O}_{3}, \mathrm{MnO}$, and $\mathrm{MgO}$. All slags contain considerable levels of $\mathrm{SO}_{3}$, which can be found primarily as $\mathrm{MnS}$ in sample $\mathrm{A}$, and $\mathrm{CaS}$ in samples $\mathrm{B}$ and $\mathrm{C}$ (Fig. 5). Heavy metals, i.e., $\mathrm{ZnO}$ and $\mathrm{PbO}$, are no longer present.

\section{Discussion}

Conventional FeMn alloys contain 75-95 wt.\% Mn with less than $6 \mathrm{wt} . \% \mathrm{Si}$, and FeSiMn alloys typically contain over 60 wt.\% Mn with 10-35 wt.\% Si [4]. The measured concentrations of $\mathrm{Si}$ (Table 3) deviate from the expected reduction in Si calculated for samples B and C in Fig. 3, which may a result of kinetic limitations in the smelting process and/ or inhomogeneities in the final metal products. Microscopic methods are limited in determining bulk material compositions, and alternative methods should be considered. All metals produced in the current experiments fall into the FeSiMn category. Si units are sought after, and such specialized alloys also find their uses in industrial applications. Commercial FeSiMn alloys are typically found to contain up to a maximum of $0.25 \mathrm{wt} . \% \mathrm{P}$, while the current level of $\mathrm{P}$ is comparable to that of premium-grade low-P alloys with concentrations close to 0.05 wt.\% P. Fe(Si)Mn alloys also have strict requirements on the presence of $\mathrm{S}$, with concentrations typically ranging from 0.01 to $0.05 \mathrm{wt} . \%$ [4]. In the current experiments, the distribution of $\mathrm{S}$ is found to depend upon the addition of $\mathrm{CaO}$. While the metal of sample $\mathrm{A}$ is measured to contain approx. $0.1 \mathrm{wt} . \% \mathrm{~S}$, which is far too high for most alloys, the concentration is reduced to acceptable levels of 0.03 wt.\% in samples B and C.
Calcium is commonly added in iron- and steel-making processes for refining, desulfurization, and modifying the remaining sulfide inclusions into $\mathrm{CaS}$, which is less detrimental to the mechanical properties of the final product. Precipitated sulfides are primarily found as $\mathrm{MnS}$ in sample $\mathrm{A}$ or as $\mathrm{CaS}$ in samples $\mathrm{B}$ and $\mathrm{C}$ (Fig. 5). $\mathrm{CaO}$ increases the basicity of the slag and extracts $\mathrm{S}$ from the metal, binding it to $\mathrm{CaS}$. The melting point of $\mathrm{CaS}$ is greater that than of $\mathrm{MnS}$, i.e., $2000{ }^{\circ} \mathrm{C}$ versus $1610^{\circ} \mathrm{C}$, improving the high-temperature properties of the metal even further. It is, however, important to note that calcium treatment cannot be applied to all kinds of steels, e.g., requiring high formability, as such treatments may generate very hard calcium aluminate inclusions. The chemical compositions of the slags in Table 4 correlate well with that predicted by the thermochemical calculations in Fig. 3b, suggesting close to equilibrium conditions. The calculations also suggest that there is an increased driving force for the alkalis to leave the system through the gas phase when adding $\mathrm{CaO}$ and is also supported experimentally. While alkalis, i.e., $\mathrm{Na}_{2} \mathrm{O}$ and $\mathrm{K}_{2} \mathrm{O}$, remain present in the slag of sample $\mathrm{A}$, their presence is mitigated by the addition of $\mathrm{CaO}$ in samples $\mathrm{B}$ and $\mathrm{C}$. The presence of $\mathrm{Zn}$ and $\mathrm{Pb}$ has also become negligible in all samples, due to their high volatility. Alkalis and other volatiles are known to cycle and accumulate and may lead to operational challenges, e.g., for submerged arc furnaces. Small concentrations of residual $\mathrm{MnO}$ remain in the slags and, according to equilibrium calculations, and additional $\mathrm{CaO}$ is needed in order to extract the remaining amounts. However, the compositions of current slags are comparable to those of conventional steel-making slags, which opens up the possibility of recycling them in construction and agricultural industries [6].
Fig. 5 Micrographs showing that sulfur is primarily found as a spherical $\mathrm{MnS}$ particles in the slag of sample A and $\mathbf{b}$ dendritic $\mathrm{CaS}$ structures in the slags of samples B and C
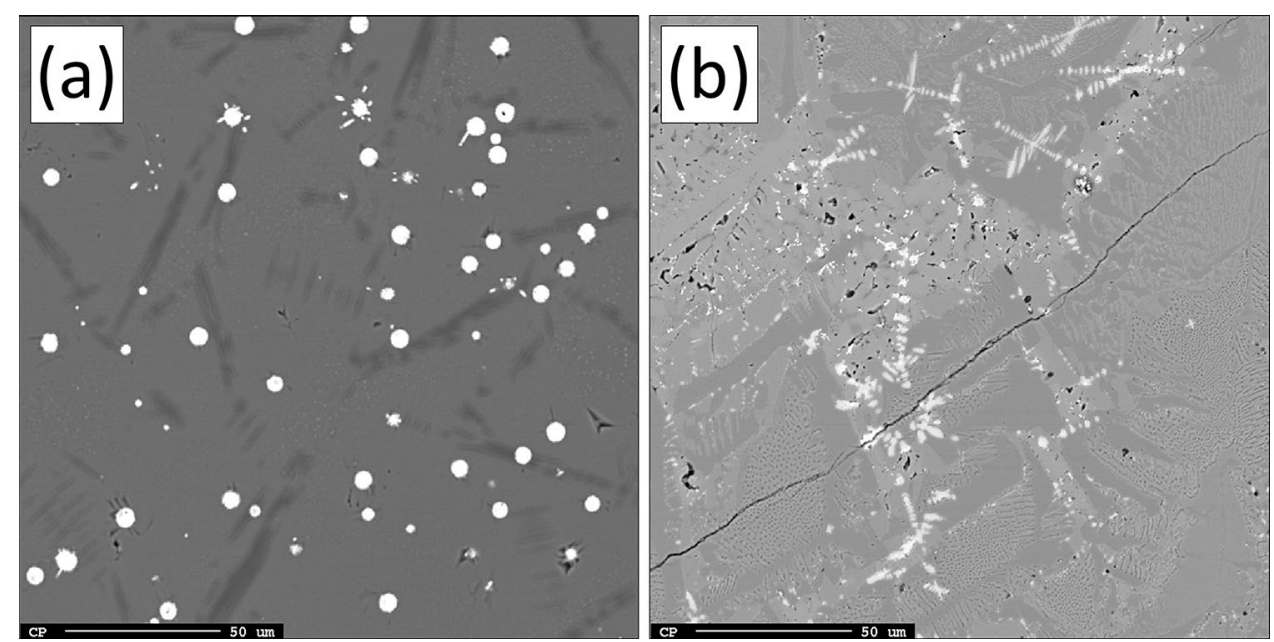


\section{Conclusions}

Current experiments present an opportunity for recycling of SiMn sludge collected from scrubbers at an industrial plant in Norway. Mixed with secondary Fe sources, the sludge has proved useful to produce FeSiMn alloys with P-levels comparable to that of premium-grade low-P alloys. Small amounts of $\mathrm{Zn}$ and $\mathrm{Pb}$ that accompany the sludge were readily removed in the off-gas at $1600{ }^{\circ} \mathrm{C}$. The presence of alkalis and $\mathrm{S}$ could be managed by adding $\mathrm{CaO}$ to the raw material mix, resulting in increased evaporation of alkalis and capture of sulfides as $\mathrm{CaS}$ in the slags. The final composition of the final slags proved to correspond to conventional steel-making slags.

Acknowledgements This paper is funded by the Waste-to-Value Project (Norwegian Research Council, Grant No. RCN 256789). The collaborations of project partners are greatly appreciated: Alcoa Norway, Elkem Technologies, Eramet Norway, Eyde, Glencore Nikkelverk, Hydro Aluminium, and ReSiTec.

Funding Open access funding provided by NTNU Norwegian University of Science and Technology (incl St. Olavs Hospital - Trondheim University Hospital).

\section{Declarations}

Conflict of interest The authors declare that they have no conflict of interest.

Open Access This article is licensed under a Creative Commons Attribution 4.0 International License, which permits use, sharing, adaptation, distribution and reproduction in any medium or format, as long as you give appropriate credit to the original author(s) and the source, provide a link to the Creative Commons licence, and indicate if changes were made. The images or other third party material in this article are included in the article's Creative Commons licence, unless indicated otherwise in a credit line to the material. If material is not included in the article's Creative Commons licence and your intended use is not permitted by statutory regulation or exceeds the permitted use, you will need to obtain permission directly from the copyright holder. To view a copy of this licence, visit http://creativecommons.org/licenses/by/4.0/.

\section{References}

1. Council of the European Union, European Parliament (2006) Directive 2006/21/EC of 15 March 2006 on the management of waste from extractive industries and amending Directive 2004/35/ EC

2. Gaal S, Tangstad M, Ravary B (2010) Recycling of waste materials from the production of FeMn and SiMn. In: Infacon XII, pp $81-88$

3. Ravary B, Hunsbedt L, Kristensen O (2013) Progress in recycling sludge from off-gas cleaning of manganese alloy furnaces. In: Infacon XIII, pp 1023-1028

4. Gasik M (2013) Handbook of ferroalloys: theory and technology. Butterworth-Heinemann, Waltham

5. Bale CW et al (2016) FactSage thermochemical software and databases, 2010-2016. Calphad Comput Coupling Phase Diagr Thermochem 54:35-53

6. Horii K, Kitano Y, Tsutsumi N, Kato T (2013) Nippon Steel Technical Report No. 104: processing and reusing technologies for steelmaking slag

Publisher's Note Springer Nature remains neutral with regard to jurisdictional claims in published maps and institutional affiliations. 